\title{
On Theology and Objectivity: A Northern Point of View to Analytic Theology
}

\author{
Olli-Pekka Vainio \\ University of Helsinki
}

\begin{abstract}
This paper has three aims. First, it provides the historical background necessary to understand the nature of academic systematic theology as it is currently being pursued in Nordic countries. Second, it questions whether the method of analytic theology is able to fulfill the desiderata of Nordic academic systematic theology. To this end, I suggest a specific methodological definition. Lastly, I assess if analytic theology can remain theological when using this methodology.
\end{abstract}

In the Nordic countries, theology is still mostly done in state-funded faculties, which have traditionally had strong connections to Lutheran state and folk churches. ${ }^{1} \mathrm{~A}$ major influence in the $20^{\text {th }}$ century in the Nordic countries has been the so-called Lundensian school, scholars of which include, for example, Anders Nygren, whose Agape and Eros has become a scholarly classic on the theology of love, and Gustaf Aulén, who offers a broad prolegomenon to the doctrine of atonement in his Christus Victor (Nygren 1953; Aulén 2003).

The Lundensian school of theology was (and still is) the internationally most important and best-known Nordic theological movement. The Lundensian school saw itself as a continuation of the general development of European theology in the $19^{\text {th }}$ century, which took influence especially from Immanuel Kant and German Liberal Protestantism. During this time, the chief religious institution in Nordic countries was still the local state church. This institution was attacked vehemently by, for example, Søren Kierkegaard and other activists in the pietistic movements who lived through the great spiritual awakenings of the $19^{\text {th }}$ and early $20^{\text {th }}$ century. These revivals created a religious other within the state church system that generated judicial and ecclesiastical tensions and later resulted in the redrafting of laws concerning religious freedom (Heikkilä and Heininen 2016). This necessitated the portrayal of official

\footnotetext{
${ }_{1}^{1}$ The Nordic countries include Sweden, Norway, Denmark, Iceland, and Finland, which, since the Reformation, have all had dominant Lutheran churches with strong links to state. In addition to faculties of theology in state-run institutions, there are several Christian bible schools and colleges linked to non-Lutheran free churches. These are primarily vocational schools for their own pastors and other workers and do not engage extensively in academic discussion. In this paper, I use often the term 'Nordic' even if I mainly speak from my own Finnish perspective. Not all Nordic institutions are alike, but many of these share similar history and vision.
}

Journal of Analytic Theology, Vol. 8, August 2020

10.12978/jat.2020-8.1411-65210014

(C) 2020 Olli-Pekka Vainio • (c) 2020 Journal of Analytic Theology 
Lutheran theology as different from that of these pietistic movements, some of which had formed their own churches while others remained in the church. Moreover, there was a need to "rescue" Christianity from external criticism and to portray it as a science. Especially problematic was the connection between religion and national identity, exemplified particularly in Nazi Germany (Rasmusson 2005). In Nordic countries, this relationship was mostly toned down, such that being Lutheran was understood to be univocal with being a good citizen and doing your daily duties (Wingren 2004).

The Lundensian school of theology sought to occupy a niche where it could thrive in this new environment. ${ }^{2}$ For example, Anders Nygren argued that Christian dogmatics needed to be scientific, as defined by Kantian philosophy, which showed that theology could not be a science in the same sense the natural sciences were. Within the walls of the university, theology was to adhere to Kantian epistemology but had to refrain from attempting to answer metaphysical questions and most importantly, the question of extrasystemic truth. However, there was still much that theology was permitted to explore-here, Nygren was echoing German thinkers like Ernst Troeltsch, Rudolf Otto, and Wilhelm Herrmann (Martikainen 2002). For Nygren, the basic method of scientific systematic theology was motif research, which tried to uncover the underlying motifs of any given system of thought (e.g., the written works of an individual author or even complicated systems, like Lutheranism or Christianity).

Scholars considered this method a way of identifying the essence of thought systems and ridding themselves of influences that compromised their objectivity. In the theological climate of the early $20^{\text {th }}$ century, the results of works that applied this methodology led to an affirmation of the Hellenistic thesis: genuine Christianity was radically dynamic and free from static metaphysics, something that was endemic to Greek philosophy but alien to early Christianity (Erling 1960; Kegley 1970).

Furthermore, Luther was taken to be the high point of "true" Christianity, the figure in whom the history of theology had found its apex. Subsequent theology was either to follow Luther or cease to be Christian. There was a tendency to draw sharp lines not only in Medieval Christianity but also in later forms of Protestant thought. This was a typical feature of the so-called Luther renaissance (e.g., Karl Holl), which on the one hand reinvigorated critical Reformation studies but on the other hand sought to emphasize the differences between Protestant and Catholic theologies, and also Luther and his students and colleagues.

From the perspective of the modern day, it seems almost amusing that Lundensians insisted that what they did was not normative or constructive theology, that they were only providing an objective description of the authentic Christian theology. They did not seek to demonstrate that Christianity was true, as this would have gone against the rules set out by Kant. Nor did they did wish for the university to serve as a pulpit (at least not directly), from which they might instruct the public on what they should believe. ${ }^{3}$

\footnotetext{
${ }^{2}$ For a concise overview of the Lundensian school, see Rasmusson (2007).

${ }^{3}$ Of course, indirectly this meant that if you wanted to base your convictions on facts, then you had no choice but to follow the objective and value-free accounts of history provided by the faculty.
} 
In the Nordic countries, much of systematic theology is still to some extent influenced by the Lundensian method. More recently, it has been mixed with a Wittgensteinian focus on language and some vaguely postliberal sensibilities, whereby liturgy as a first-order religious discourse is left to the church, while theology as a second-order discourse is considered the business of the university, an institution tasked with cataloguing how religious language is being used across various linguistic communities (Kerr 1988; Lindbeck 2007). In this capacity, academic theology is not normative, since it only explains what people are trying to say when they use religious language. This development had perhaps a tacit apologetic motive in that it offered a form of theological study that might satisfy those academic critics who had argued that there was no room for theology in the modern research university.

The Nordic faculties of theology have also seen a shift towards the American religious studies model as societal needs have changed. Until the 70s and $80 \mathrm{~s}$, the state faculties were effectively (but not officially) seminaries, but this is no longer the case. The faculties still train pastors, but the demand for new pastors has been diminishing quickly as the membership of the Lutheran folk churches have rapidly dwindled. Secularization took a hefty toll on the folk churches, while significantly smaller Evangelical, Catholic, and Orthodox communities continue to grow, mainly due to immigration. When I began my studies in 1996, 93\% of Finns were still Lutheran; today, the figure is $69.3 \%$. In response, the faculties of theology are trying to reinvent themselves, direct resourcing, for instance, to conflict resolution and programs that seek to address issues like multiculturalism. ${ }^{4}$ Thus, we find ourselves in a new academic context, where the first important, though hardly new, goal is objectivity and the second is to address growing pluralism in the world.

To address the first goal, state faculties have typically adhered to the general methodological distinction between explanation and understanding (von Wright 2004). While the natural sciences explain phenomena by observing cause and effect, the social sciences aim to understand phenomena through participation. In the case of systematic theology, this participation is undertaken by close reading texts. The role of theology is not to criticize particular religious or dogmatic views, nor should it should attempt to explain what they are really about. Theology should rather increase the understanding of religious texts and phenomena.

In general, Nordic theology has tried to resist the urge to explain away religious phenomena or religious doctrines, since the chief methods (Lundensian motif research and more recent textual close reading) have tried merely to understand the meaning of doctrines. Some theologians have nonetheless openly adopted the explanation model. On the one hand, especially in the biblical studies, the history of religions school has tried to offer genetic readings of the history of Christian dogma, which are both critical and normative (Räisänen 2010). On the other hand,

\footnotetext{
${ }^{4}$ For example, the Faculty of Theology in the University of Helsinki describes itself in this way on its website: "The Faculty of Theology prepares students for duties requiring expertise in religions, worldviews and values. The Faculty studies the individual, cultural and social significance of religions from times past to the present. We are an international academic community, unaffiliated with any particular religion or belief."
} 
the close-reading method ends up simply restating in a more concise form what the source already says, with the help of so-called "structural principles," which are the presuppositions or basic commitments that guide the thought process of the subject. ${ }^{5}$ Here, the line between understanding and explanation is difficult to discern. To what extent does describing a structure of thought effectively explain (or explain away) what the source says? As many have pointed out, it is indeed difficult to separate explanation from understanding. Explanation increases our understanding of phenomena, while understanding may lead to further explanations. In this way, academic theology has always steered towards normativity, regardless of its intentions to do otherwise. At the same time, the Nordic faculties typically underline that they are not affiliated with any one religious tradition, that they are denominationally neutral, and that their methods aim at objectivity. However, this demand for objectivity is not well-defined and there is no recent good literature on what it could mean. Depending on the context people may mean different things with it and this vague demand puts a straightjacket on theology, which is not always fair. Next, I will assess how analytic theology might fit into this picture.

\section{Analytic theology in a secular context: Is it objective?}

Thomas H. McCall has offered brief answers to some basic criticisms of analytic theology (McCall 2015). These criticisms arise typically from philosophical or theological concerns endemic in Anglophone Christian theological traditions. Some fear that analytic theology is not theological enough or that it is based on the wrong philosophical presuppositions. These issues are natural for institutions with creedal statements or strong adherence to particular theological identity or style. These concerns, and other similar challenges, have already been well addressed in previous scholarship. ${ }^{6}$

I wish to raise additional concerns that have not yet been discussed at length. ${ }^{7}$ My questions are as follows: What can analytic theology offer to systematic theology, in an increasingly secular and increasingly pluralistic Nordic context? Can analytic theology justifiably find a place in the modern European research university?

I start answering these questions by taking a closer look at what analytic theology understands itself to be. What is the method of analytic theology? James Arcadi defines analytic theology according to four desiderata, which he also grounds historically in certain medieval figures who had promoted the method of "declarative theology" (Arcadi 2017). According to Arcadi, analytic theology

\footnotetext{
${ }^{5}$ Structural principles are not the same as motifs in the Lundensian method, as they are not supposed to explain why a person thinks as he or she does.

${ }^{6}$ See also Wood (2014).

${ }^{7}$ McCall (2015) does not discuss the objection that analytic theology is only useful for conservative apologetics. He points out that, as a method, analytic theology can be freely applied to other purposes. Coakley (2013) does mention this issue, arguing that there are too few apologetics for a robust Christian theology and that the apologetic objective should be welcomed as an aim of analytic theology.
} 
1) Offers clarification of terms that are used in doctrinal discourse.

2) Offers defeaters to possible defeaters.

3) Offers analogies that might help the faithful to better imagine what doctrinal claims mean.

4) Offers arguments that raise the probability of these claims being true.

Arcadi states that "in this mode of theologizing, the articles of faith function as conclusions in theological arguments. The declarative theologian seeks to find premises that support these conclusions or they seek to defeat arguments that have positions contrary to the articles of faith as their conclusions" (50).

In the Nordic context, the tenets one and three are entirely unproblematic. It is the second and fourth tenets, however, which may cause concern. For example, observing Nordic dissertations in systematic theology, one notices that they are typically descriptive: they just summarize what the given historical or contemporary author or authors say. Dissertations are not supposed to criticize or correct the authors, and they are not supposed to offer novel arguments for or against the views of the authors. However, given the existing rules, one may analyze the success of the arguments from intrasystemic perspective. This means that one may judge the success of an argument or coherency of a claim based on whether it actually follows from other premises the author holds true. ${ }^{8}$ So given these constraints, there is no reason why the second tenet could not be accepted in the Nordic systematic theology method. ${ }^{9} \mathrm{~A}$ further issue concerns the role of extrasystemic defeaters, which is linked to Arcadi's tenet four.

If I have reason to believe that something is more probable than not, I should likewise have reason to think that this belief exerts some kind of normative power over me, that is to say, I now have epistemic reason to believe the given proposition. Consequently, in this case, I cannot remain neutral about the issue, although I can still insist that I have reached this conclusion through means and methods, which are objective. Of course, it isn't at all obvious why an intellectual activity should aim at "neutrality" in any interesting sense of that word. Insofar as natural science aims to arrive at the truth by way of gathering evidence and testing hypotheses, natural science is necessarily not neutral with respect to the question of which hypotheses are more likely to be true.

In the philosophy of science, the notions of "neutrality" and "objectivity" have long been debated, and, at the moment, it seems that we are unable to provide a one-

\footnotetext{
${ }^{8}$ For example, one could state that Martin Luther's late views on Jews are incoherent and theologically poor, given his earlier positive writings on Jews.

${ }^{9}$ One of the reviewers pointed out that in fact Arcadi's tenets two and four are not that different from each other since both can in principle involve making claims about what one has reason to believe. The difference may lie only in the context where the arguments are discussed and presented. On the one hand, one may examine whether certain claims do indeed follow from certain assumptions or premises, which is one way one could defeat an alleged defeater to a belief system. On the other hand, one could show that an alleged item of counter-evidence in fact isn't counter-evidence against the belief-system. I am thankful for this comment.
} 
size-fits-all definition for scientific neutrality and objectivity. ${ }^{10}$ Nonetheless, it is selfevident that good science should strive towards some kind of objectivity (Reiss 2014; Daston and Galison 2007). To be precise, the key word on my Faculty's website is "unaffiliated," which primarily means that the faculty does not officially endorse in its teaching any particular denominational or religious point of view. Although the main concern is pragmatic it presupposes a deeper methodological assumption on how theology is supposed to be done. In this sense, the faculty wants to remain "neutral" and the research it carries on is supposed to follow "objective" standards. Tacit underlying worry behind these commitments concerns the status of theology as an academic discipline, which deserves to be taught in secular universities. ${ }^{11}$ To ease the critics, the faculties try to adopt methodologies, which try to avoid normative stances. The teaching is intended to raise the understanding of religious form of life and not offer arguments for a particular interpretation of a religious doctrine. While this strategy can track certain intellectual virtues, it often lacks needed rigor and clarity. For example, it can be asked whether neutrality is possible or desirable in the first place, and if so, should we impose such a demand also to say, ethics and political science? Of course, this would make no sense. But if the secular universities wish to keep on teaching theology, they will quite likely use some kind of language of neutrality and objectivity when giving grounds for their stance. The problem lies in how this aspiration is materialized in teaching and research. I personally find the language of neutrality unhelpful because it is too vague. Here I wish to offer some options for what could be meant by neutrality.

a. Indifference: "I do not care what is true."

b. Impartiality: "I do not take sides in debates."

c. Conciliation: "I must compromise between different sides of the debate."

d. Detachment: "I must remain detached from the topic, which I study and make no commitments."

e. Consensus: "I must begin my reasoning from premises that are universally acceptable."

Let us examine each of these in turn. Indifference may well be the initial attitude of many towards philosophical or theological questions (and sometimes even a desirable attitude), but it fails to account for the gravity of theological questions, which, like ethical questions, are existentially demanding and risky. Therefore, it is unwise to treat them categorically as unworthy of serious consideration. Furthermore, everyone is already so embedded in the same world that we cannot escape from conceiving of some ideas about ultimate reality, which in turn functions as the basis for our actions.

\footnotetext{
${ }^{10}$ It is perhaps worth noting that, even in a case where all participants approve of naturalism, there might still be no consensus concerning proper philosophical methods and distinctions (Kornblith 2016).

${ }^{11}$ In Europe, this has been a long debate. One of the early examples of this in modern times was Immanuel Kant's The Contest of Faculties (1798).
} 
Impartiality may, in some cases, be an intellectual virtue, especially if one has investigated an issue only superficially. However, eventually people fail to stop with an impartial investigation; they take sides. Sometimes not taking a side effectively means endorsing particular point of view or status quo. ${ }^{12}$

Conciliation presumes that some kind of neutrality must be the result of investigation. Yet it is hard to see how this could play out in the real world. This proposition bears close resemblance to some non-cognitive forms of theology, where all problems and disagreements are solved by moving the dispute to another level and explaining how the dispute is not in fact about what it seems to be about (Phillips 2002). The obvious problem here is that, to accept this solution, one would need to subscribe to several other theses, many of which will be controversial in their own right.

Detachment implies that academic inquiry must follow certain rules and aspire to certain virtues. The problem here is how we should think about detachment. It seems that it can sometimes be a force of good, while, at other times, detachment can sometimes hinder our judgments or result in outright vicious actions through neglect. Consensus, on other hand, is far too demanding. It is difficult to get anything started with the expectation of reaching consensus, especially outside the hard sciences.

It seems that there is no good definition for what neutrality could mean in this context since the common definitions are either unsuitable for high academic ideal or practically unworkable. If we try to pay attention to the initial concern behind the demand for neutrality, it would be better to shift the emphasis towards objectivity. I propose that in this context objectivity could be defined as methodological transparency: when offering an account of a religious phenomenon or propositional claim, one needs to make sure that everything one does is expressed openly and clearly. This means that I should lay out my fundamental premises and the criteria I will be using in my reasoning, an approach that comes close to what Mike Rea has expressed in his five prescriptions for analytic theology (Rea 2009, 4):

P1. Write as if philosophical positions and conclusions can be adequately formulated in sentences that can be formalized and logically manipulated.

P2. Prioritize precision, clarity, and logical coherence.

P3. Avoid substantive (non-decorative) use of metaphor and other tropes whose semantic content outstrips their propositional content.

P4. Work as much as possible with well-understood primitive concepts and concepts that can be analyzed in terms of those.

P5. Treat conceptual analysis (insofar as it is possible) as a source of evidence.

Again, the first four points here are not problematic as they embody well what we could mean by objectivity as transparency. The issue of normativity in the fifth point might still trouble someone, but in order to argue against P5 one would have to claim that there can never be reasons for thinking that theological or philosophical

\footnotetext{
${ }^{12}$ For a thorough criticism of alleged impartiality, see Clouser (2005).
} 
propositions have a truth value. ${ }^{13}$ Insisting on this would require further investigation and it cannot be approved without argument. Why should one think that public evidence is not a meaningful category in philosophy and theology? There are good arguments against this view (Swinburne 2013; Wolterstorff 1998).

If one does not wish to engage in a debate where he or she seeks to take down Kant and Wittgenstein before making any further claims, one way forward could be the following. ${ }^{14}$ We can set some desired state of affairs as our goal. We need not take sides a priori as to whether this state of affairs is objectively or universally good or in what sense it might be said to be true. We can remain neutral about the goal while still taking sides regarding the normative relationship between the means and the goal. The reasoning might then follow this technical norm:

Technical norm for analytic theology (TNAT): If you want to achieve goal $G$ and you are in situation $B$, then you should do $M$.

$G$ can now be defined as anything that is within the interests of a particular group. It is obvious that these interests cannot be universally shared, at least prima facie. The goals can also be rather imaginative, risky and outlandish. You might then define certain boundaries $(B)$ that restrict the moves available for you. These moves are the means $(M)$ that should take you to $G$. In a theological context, we might consider about the following case:

G: demonstrating the coherency of Chalcedonian Christology

$B$ : canonical and conciliar texts

$M$ : the moves afforded to me within B to achieve G

How does TNAT stack up against the aforementioned ideals of objectivity? TNAT does not presume the truth of $B$ or the objective goodness of $G$. It is only $G$ that is valueladen, while the causal process that should take one from $B$ with the help of $M$ to $G$ remains value-neutral. This causal process is supposed to portray transparency so that it can be assessed by anyone. This is a norm of objectivity, which is practically achievable and defined to a sufficient degree. Objectivity is respected so long as one's commitment to the goal does not interfere with how the causal relationship between $M, B$, and $G$ might assessed. ${ }^{15}$

It is noteworthy that $B$ as such falls short of being neutral, since it is a particular situation with particular characteristics, but this is not a problem for objectivity. For example, in chess, your goal is to deliver a checkmate according to a given set of rules. We can objectively analyze various tactics and propose strategies

\footnotetext{
${ }^{13}$ A possible argument for this would be based on Kantian or Wittgensteinian presuppositions.

${ }^{14}$ I follow and modify here Ilkka Niiniluoto's account of critical realism (Niiniluoto (1999), 250-251).

${ }^{15}$ One of the reviewers pointed out that TNAT, on its own, is simply a statement of what it is to pursue a goal in a practically rational manner in general. I agree. But is there something that makes a difference in the pursuit of analytic theology? Yes, there is. TNAT allows, within the strictures of objectivity, to insert into TNAT any values one wishes to test and analyze. In other words, analytic theology in the Nordic context would include TNAT and the values coming from given theological tradition, which are then tested in transparent way.
} 
that most effectively help one to win the game without making any recommendations about whether one should play this game and not some other game or whether this particular configuration of rules is the best set of rules. This is not special-pleading on behalf of theology as this is how value-neutrality has traditionally been argued for in the social sciences. ${ }^{16}$

Someone might claim that $B$ in some actual case is fundamentally ambiguous or underdetermined by the evidence, and we should therefore not be restricted by $B$. Two points can be made in response to this: on the one hand, it is one thing to assess the philosophical coherence of a doctrine and another thing to assess the genealogy of the material that is seen as supporting, say, Chalcedonian Christology. ${ }^{17}$ These approaches should be seen as methodologically different. That is why analytic theology needs to have close connections to historical and exegetical theology.

On the other hand, it seems that philosophical views might affect, for example, exegetical methods, and exegetical results might in turn affect our understanding of which philosophical solutions are viable (Plantinga 1998). Christological debates are a case in point. If one thinks that Chalcedonian Christology is a priori irrational, this quite naturally affects how the Bible is read and interpreted. This is why other fields of theology and religious studies would probably benefit from the presence of a couple analytic theologians.

Even if $B$ is often taken as a given within the system and therefore unchangeable, this need not be the case. In TNAT, one might freely use $B$ as a starting point, but the inquiry might still lead one to conclude that $G$ is unattainable within $B$, unless some adjustments are made. ${ }^{18}$ This is the point at which extrasystemic normative statements are welcomed. But this is no simple matter, as it can be difficult to evaluate on what grounds we might be justified in claiming that the route from B to $G$ is blocked. The problem concerns the notion of evidence. I have already pointed out how a definitions for neutrality and objectivity are not easy to come by, and the same applies to the criteria for evidence (Williamson 2007; Cappelen 2017). In theology, it can likewise be difficult at times to say what counts as evidence and what does it entail (Dougherty 2017). For this reason, defining neutrality as transparency should work here quite well. In the event of disagreement, each party should strive to make their belief-policies and hermeneutical practices as transparent as possible so as to be able to explain to the other how and why they reached their conclusions.

Why, then, would secular research universities be interested in these kinds of thought-experiments? They should be for the same reason they are also interested in exploring any ethical, philosophical and political questions. State-funded universities generally serve the public needs, and, if there is a large segment of the population burdened with a set of questions of societal relevance, they have good reason to invest resources into investigating these questions, especially when pluralism is on the rise and people lack the skills of understanding even the basic concepts of familiar

\footnotetext{
${ }^{16}$ Eleonore Stump also implies a similar approach in her recent account of the methodology of philosophical theology (Stump (2018), 1-10).

${ }^{17}$ For the former, see Pawl (2016); for the latter, see Anatolios (2011).

${ }^{18}$ Something like this in Christology is suggested by, e.g., Cross (2009).
} 
traditions. In doing this, universities can serve the public in at least the following ways.

a. Improving civil discourse by improving understanding of claims people make.

b. Making people of various religious communities feel at home in their societies to which they contribute, among other things, taxes and public services.

c. Promoting openness, critical thinking and other intellectual virtues by publicly investigating claims made by various worldviews.

This is, however, still a thin argument, and it does not capture all the essential features of analytic theology. We could make a thicker argument by including an element Alasdair MacIntyre argues for in his God, Philosophy and Universities:

d. Seeking by inquiry the unity of all knowledge and the interrelatedness of all disciplines.

This point could effectively include the claims of universality and normativity. Modern research university could, however, brush aside these public goods in one of two ways, which I find both short-sighted and betraying the idea of university. First, by claiming that these forms of inquiry are not fiscally productive; second, by claiming that some forms of inquiry can be rejected outright. In these cases, the university would cease to be a university, which is sadly not outlandish in today's world. MacIntyre reminds us that this is not an encouraging scenario, but the history tells us that things have only rarely, if ever, been different so we might not in the end be worse off than our ancestors (MacIntyre 2009).

\section{AT in a secular context: Is it theology?}

Even if we grant that TNAT would satisfy the requirements for objectivity of enquiry in a secular university, one might still think that theology is paying too high a price. What I have presented above is not a pathway for analytic theology to achieve the status of "the queen of sciences". More precisely, it might seem that, in TNAT, the question of truth is reduced to the level of an idiosyncrasy of a marginal interest group. TNAT might produce results that have truth-value, but only in the form of that particular mode of action $M$ which holds true for those who are already members of the group in which it carries a positive conative valuation for $G$. Should theology not make public truth claims that are true for everyone, not just for a few? Should theology not matter to everyone?

In Europe, there is a long history of trying to make theology matter. The German tradition, for instance, has long tried to make theology matter, but they have struggled to determine how to make it matter. Famously, Adolf von Harnack was infuriated by Karl Barth, after the latter published his Römerbrief particularly for this 
reason: Barth was trying to make theology matter illicitly (Robinson and Moltmann 1968). Some theologians might have similar concerns that analytic theology has tried to make theology matter in the wrong way-that is, by insisting that traditional creedal Christianity, broadly understood, is still credible for the modern person who uses "electric lights and radios." 19

The result often seems to be a thinning of theological content. After peeling off the supposedly mythological layers of theology, little else remains, and those working in the field tend vehemently to disagree with one another about what remains, once all the unoriginal and foreign elements have been removed. Another concern is the elitism that follows from such a thinning. Schleiermacher's Reden proves this point forcefully. Schleiermacher's project makes theology and religion elitist or so abstract that only a select few can hope to benefit from it, something that Schleiermacher himself acknowledges, when he describes his ideal congregation as a small communion of a few enlightened minds (Schleiermacher 1893). Paradoxically, the attempt to make Christianity a cultural force seems to lead one into an old boys' club, from which all non-intellectuals are excluded. ${ }^{20}$

From this point of view, the Barthian concerns are warranted. Theology should be theological (Webster 2015). Such a postliberal/Barthian move, which sees theology as a self-sustained discourse, needing no external support, might grant some momentary peace of mind to the community to pursue their own thoughtexperiments, but this would isolate theology from the questions and debates that are relevant to society as a whole. ${ }^{21}$

Methodologically, analytic theology can be taken as a thought experiment that begins with a set of presuppositions without first trying to justify the use of those presuppositions and claims to adhere to objective means. This picture fits quite well with the postliberal model (Marshall 2002). However, analytic theology wishes to say that theology can and should make publicly accessible reality claims, which are not just about how the language is used in Christian communities. Something like this is implied in Rea's fifth prescription:

P5. Treat conceptual analysis (insofar as it is possible) as a source of evidence.

What conceptual analyses can be considered evidence for the truth of Christian faith are those in which it is possible to demonstrate that a) the terms are used coherently, b) defeaters are rebutted in a reasonable manner, c) there are analogies that render the claims at least somewhat understandable, and d) some views can be taken as more plausible than the others. If these criteria are fulfilled, then the inquiry ends up favoring some views over others. TNAT is therefore also open to public rebuttal and falsification. If it becomes obvious that $G$ cannot be achieved within $B$, then no moves are possible. This would serve as evidence for $G$ being an implausible goal or unworthy of exploration within $B$. TNAT steers methodologically away from both the

\footnotetext{
${ }^{19}$ As Rudolf Bultmann famously noted, "We cannot use electric lights and radios and, in the event of illness, avail ourselves of modern medical and clinical means and at the same time believe in the spirit and wonder world of the New Testament" (Bultmann 1984, 4).

${ }^{20}$ Further on this, see Vainio (2018).

${ }^{21}$ For an apology for theology to become public in this sense, see Hütter (1999).
} 
premature reductionism of old liberal Protestantism and Barthian isolationism. If the claims of Christian theology are refuted or revised, they are done so only after rigorous public engagement. And if they stand and hold their ground, they gain in credibility, which should affect even those outside of faith communities.

By definition, secular Nordic universities cannot directly support particular religious, philosophical, or political views. Secular universities should instead be committed only to certain intellectual virtues, like open-mindedness, honesty, wisdom, and the love of truth. ${ }^{22}$ Pursuing these virtues will lead individual scholars to particular conclusions that are favored over others. The best context for these kinds of claims and convictions, then, is a university that is committed to intellectual virtues. As MacIntyre states about philosophy:

Philosophy is in any case a social and not a solitary form of enquiry. It requires a setting in which different and rival answers to philosophical questions can be proposed and objections to each considered in detail, so that such answers may be revised or rejected and such objections themselves subjected to critical scrutiny. And, if the enquiries of philosophy are to be sustained enquiries, as they need to be, they must be continued through different philosophical generations, each of which in turn has to be introduced through to the enquiries and debates that have made philosophical questions what they have become in that particular time and place. Moreover, philosophy cannot but draw upon the findings and insights of other disciplines so that the type of institutionalized setting in which it is most likely to flourish is that of a college or university. (MacIntyre 2009, 17)

Replacing the word "philosophy" with "theology" (or "analytic theology") in the quote above would in my mind reflect well the role and place of analytic theology in the contemporary university.

${ }^{22}$ For accounts of intellectual virtues, see, e.g., Baehr (2016); Timpe and Boyd (2015). 


\section{References}

Anatolios, Khaled. 2011. Retrieving Nicaea: The Development and Meaning of Trinitarian Doctrine. Grand Rapids, MI: Baker Academic.

Arcadi, James M. 2017. "Analytic Theology as Declarative Theology." Theologica, 3752.

Aulén, Gustaf. 2003. Christus Victor: An Historical Study of the Three Main Types of the Idea of Atonement. Eugene, OR: Wipf \& Stock.

Baehr, Jason S. 2016. Intellectual Virtues and Education: Essays in Applied Virtue Epistemology. New York: Routledge.

Bultmann, Rudolf. 1984. New Testament and Mythology \& Other Basic Writings. Minneapolis, MI: Fortress Press.

Cappelen, Herman. 2017. "Disagreement in Philosophy: An Optimistic View." In The Cambridge Companion to Philosophical Methodology, edited by Giuseppina D'Oro and Soren Overgaard, 56-76. Cambridge: Cambridge University Press.

Clouser, Roy A. 2005. The Myth of Religious Neutrality: An Essay on the Hidden Role of Religious Belief in Theories. South Bend, IN: Notre Dame University Press.

Cross, Richard. 2009. "The Incarnation." In The Oxford Handbook of Philosophical Theology, edited by Michael C. Rea and Thomas Flint, 452-75. Oxford: Oxford University Press.

Daston, Lorraine, and Peter Galison. 2007. Objectivity. New York: Zone.

Dougherty, Trent. 2017. "Evidence and Theology." In Oxford Handbook of the Epistemology Pf Theology, edited by William J. Abraham and Frederick D. Aquino, 236-52. Oxford: Oxford University Press.

Erling, Bernhard. 1960. Nature and History: A Study in Theological Methodology with Special Attention to the Method of Motif Research. Lund: C. W. K. Cleerup.

Heikkilä, Markku, and Simo Heininen. 2016. A History of the Finnish Church. Riga: Suomalaisen Kirjallisuuden Seura.

Hütter, Reinhard. 1999. Suffering Divine Things: Theology as Church Practice. Grand Rapids, MI: Eerdmans.

Kegley, Charles. 1970. The Philosophy and Theology of Anders Nygren. Carbondale: Southern Illinous University Press.

Kerr, Fergus. 1988. Theology after Wittgenstein. Oxford: Blackwell. 
Kornblith, Hilary. 2016. "Philosophical Naturalism." In The Oxford Handbook of Philosophical Methodology, edited by Herman Cappelen, Tamer Gendler, and John Hawthorne, 147-57. Oxford: Oxford University Press.

Lindbeck, George A. 2007. The Nature of Doctrine: Religion and Theology in a Postliberal Age. 25th Anniversary Edition. Louisville, KY: Westminster John Knox Press.

MacIntyre, Alasdair. 2009. God, Philosophy, Universities. London: Continuum.

Marshall, Bruce. 2002. Trinity and Truth. Cambridge: Cambridge University Press.

Martikainen, Eeva. 2002. Religion Als Werterlebnis: Die Praktische Begründung Der Dogmatik Bei Wilhelm Herrmann. Göttingen: Vandenhoeck \& Ruprecht.

McCall, Thomas. 2015. Invitation to Christian Analytic Theology. Downer's Grove: IVP.

Niiniluoto, Ilkka. 1999. Critical Scientific Realism. Oxford: Clarendon.

Nygren, Anders. 1953. Agape and Eros: The History of the Christian Idea of Lovee. London: SPCK.

Pawl, Timothy. 2016. In Defense of Conciliar Christology. A Philosophical Essay. Oxford: Oxford University Press.

Phillips, D. Z. 2002. "Propositions, Pictures and Practices." Ars Disputandi 2 (1): 16174.

Plantinga, Alvin. 1998. "Two (or More) Kinds Of Scripture Scholarship." Modern Theology 14 (2): 243-78.

Räisänen, Heikki. 2010. The Rise of Christian Beliefs. The Thougth-World of the Early Christians. Minneapolis, MN: Fortress Press.

Rasmusson, Arne. 2005. "Church and Nation-State: Karl Barth and German Public Theology in the Early 20th Century." Nederduitse Gereformeerde Teologiese Tydskrif 46 (3): 511-24. 2007. “A Century of Swedish Theology." Lutheran Quarterly XXI (2): 125-62.

Rea, Michael C. 2009. "Introduction." In Analytic Theology, edited by Oliver Crisp and Michael C. Rea. Oxford: Oxford University Press.

Reiss, Julian. 2014. "Scientific Objectivity." Stanford Encyclopedia of Philosophy.

Robinson, James, and Jürgen Moltmann, eds. 1968. The Beginnings of Dialectic Theology. Richmond: John Knox Press.

Schleiermacher, Friedrich. 1893. On Religion. Speeches to Its Cultured Despisers. Tr. John Oman. London: Paternoster house. 
Stump, Eleonore. 2018. Atonement. Oxford: Oxford University Press.

Swinburne, Richard. 2013. "Why Hume and Kant Were Mistaken in Rejecting Natural Theology." In Knowledge, Action, Pluralism: Contemporary Perspectives in Philosophy of Religion, edited by Sebastian T. Kołodziejczyk, 31-48. Frankfurt: Lang.

Timpe, Kevin and Craig Boyd, eds. 2015. Virtues and Their Vices. Oxford: Oxford University Press.

Vainio, Olli-Pekka. 2018. "The Concept of God and the Demise of Mainline Protestantism." Kerygma Und Dogma 64: 68-78.

Webster, John. 2015. "What Makes Theology Theological?" Journal of Analytic Theology 72 (2): 160-69.

Williamson, Timothy. 2007. Philosophy of Philosophy. Oxford: Blackwell.

Wingren, Gustaf. 2004. Luther on Vocation. Eugene, OR: Wipf \& Stock.

Wolterstorff, Nicholas. 1998. "Is It Possible and Desirable for Theologians to Recover from Kant?" Modern Theology 14 (1): 1-18.

Wood, William. 2014. "Analytic Theology as a Way of Life." Journal of Analytic Theology 2 (May): 43-60.

von Wright, Georg H. 2004. Explanation and Understanding. Ithaca, NY: Cornell University Press. 